\title{
Analysis of the Macroeconomic Stability Indicators Changing Dynamics in Ukraine
}

\author{
Olena P. Slavkovai, Marita M. Shynkarenko ${ }^{i i}$, Olena M. Korobets ${ }^{i i i}$
}

The concepts of macroeconomic stability and stabilization are analyzed in the article. The stabilization policy influences the behaviour of all economic entities, and thus, the efficiency of the national economy. Any country with a market economy tries to achieve the macroeconomic stability. Macroeconomic stability describes, firstly, the efficiency of all factors in the economic development, secondly, the efficiency of the country's economic policy. Stabilization is a complex concept, which takes into account the state of all components in the economic system. Stabilization concept has to be observed not as a state, but as a strategic process, which consists in the approximation to the economic stability. If the state's economic policy defines the stabilization criterion as a lack of concrete economic indicators, the macroeconomic disproportions will be inevitably raised. The consequences of these macroeconomic processes, which affect the country's important indicators, such as country's international image improving, rating increase in the global indicators, the native production competitiveness increase, obtaining of the stable income by business, increase in budget revenues, increase in the real wages and social benefits level, etc., are paid much attention. The dynamics of changes due to the selected indicators and the prediction of the country's economic stability further development are considered. Today the current macroeconomic system of our country relates to the unstable economy, and that is why it causes the urgent need to develop an effective national strategy aimed at achieving economic stability and growth. Based on the international experience, the authors of the article highlight and systematize the main indicators and principles of macroeconomic stability, which are reasonable to be used in Ukraine.

Keywords: macroeconomic stability, stabilization, economic balance, stability indicator, inflation, gross domestic product, exchange rate.

УДК 330.101.541:330.36(477)

JEL Codes: E60, O11, O47

Introduction. At the modern stage in the development of world economy, the issues on the improving mechanism to provide the country's macroeconomic stability are of great importance, since consequences of this stability affects a number of significant indicators: the country's international image improving, rating increase in the global indicators, the native production competitiveness increase, obtaining of the stable income by business, increase in budget revenues, increase in the real wages and social benefits level etc. Since our country's current macroeconomic system may relate to the unstable economy, it causes the urgent need to develop an effective national strategy aimed at achieving economic stability and growth.

Problem statement. The aim of the research is to describe and to analyze the dynamics of macroeconomic stability changes in Ukraine, in order to provide the balance between main

${ }^{i}$ Olena P. Slavkova, D.Sc. (Economics), Professor, Head of Accounting Department, Sumy National Agrarian University;

${ }^{i i}$ Mariia M. Shynkarenko, Postgraduate Student of the Department of Economics, Entrepreneurship and Business Administration, Sumy State University;

${ }^{\text {iii }}$ Olena M. Korobets, Leading Specialist of the Educational and Scientific Institute of Finance, Economics and Management named after Oleg Balatsky, Sumy State University.

(C) O. P. Slavkova, M. M. Shynkarenko, O. M. Korobets, 2018.

https://doi.org/10.21272/mer.2018.82.12

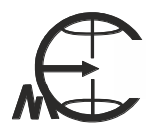

Mechanism of Economic Regulation, 2018, No 4 
economic indicators and to find possibilities to bring the country's economy to a more stable level.

Analysing of the main results. Stability is the achievement of such a state of the economic system, which can be maintained for a long time thanks to the peculiar regulatory means. Along with stability, there is a stabilization concept, which has to be observed not as a state, but as a strategic process, which consists in the approximation to the economic stability.

Stabilization is a complex concept, which takes into account the state of all components in the economic system. If the state's economic policy defines the stabilization criterion as a lack of concrete economic indicators, the macroeconomic disproportions will be inevitably raised.

The stabilization policy influences the behaviour of all economic entities, and thus, the efficiency of the national economy. Any country with a market economy tries to achieve the macroeconomic stability [1].

The macroeconomic stability is a progressive development of the economy, which provides the achievement of the stable economic growth with stable prices and low level of unemployment, with stable national currency, free capital flows, including foreign capital without high inflation for a long time, and is implemented by the state to create conditions, promoting investments and savings [2].

The macroeconomic stability means:

- firstly, the economic growth ensured through the production efficiency improve using the achievements of science and technology;

- $\quad$ secondly, full employment - providing with working places everyone, who wants and is able to work;

- thirdly, the stable prices, since if the prices grow, it will complicate the economic relations among economic entities, it will reduce the inhabitants' real incomes and devalue savings;

- fourthly, balance in foreign economic relations demonstrated in the stable exchange rate of the national currency and active payments balance [3].

In general, the macroeconomic stability consists in overcoming the macroeconomic imbalances. It is characterized by fluctuations of the national product volume, prices and employment levels, lack of conditions for steady growth in GDP. In the traditional market economy, the fluctuations of these dimensions are mainly of cyclical nature, that is why the macroeconomic stabilization reduces the amplitude of deviations and decreases the depth of the recession. It obtains the specific place in the economic policy, which helps to bring the real GDP to its potential level, and thus, to achieve the full employment and stable prices. Under such conditions, there is practically no cyclical unemployment, the inflation is stable minimum in the economy [4].

The macroeconomic stability is considered to be some balance between total demand and supply. This principle is manifested in the proper macroeconomic parameters, which have to correlate with each other. These parameters reflect relationship and interdependence of real economic and financial processes development and can be conditionally divided into two groups.

The first group includes general economic indicators, the main of which are gross domestic product (GDP) and gross national product (GNP), gross investments and gross savings, the position of payment and trade balances, indicators of employment and unemployment level.

The second group comprises monetary and financial indicators, the main of which are the size of money supply and its structure, inflation and the exchange rate of the national currency, the central bank rate and interest rates on commercial banks' loans, the budget deficit and the size of state's internal and external debt [5]. 
Olena P. Slavkova, Mariia M. Shynkarenko, Olena M. Korobets. Analysis of the Macroeconomic Stability Indicators Changing Dynamics in Ukraine

In order to assess the macroeconomic stability, about twenty indicators are used in the world practice. According to Copenhagen criteria, the main economic criterion of the Euro members' convergence is macroeconomic stability, which consists of four criteria and five indicators [6]:

the ratio of the state deficit to GDP (high state deficit causes the rapid increase of the state's debts and the deterioration of its debt security. According to Maastricht criteria, this ratio should not exceed $3 \%$ );

ratio of the state debt to GDP (the low state debt in relation to GDP indicates the country's economic growth rates and possibility for the state to perform its main functions, so then the government will be able to use tax revenues to solve internal needs, instead of covering the external obligations; according to the above criteria this ratio should not exceed $60 \%$ );

adequate stable prices and average inflation rates (this indicator should not exceed three better indicators of the member states more than $1.5 \%$; according to Maastricht criteria the inflation level does not exceed $3 \%$ );

the long-term nominal interest rate should not exceed three better indicators of the member states' price stability more than $2 \%$ (the low long-term interest rate means that the economy is stable and, likely, it will be in such condition given the stable future inflation expectations. While the current rates of inflation may be low, the high level of long-term rates considers higher inflation in future; the normal deviation of the national currency exchange rate should not exceed the thresholds, provided by the exchange rate mechanism of the member states, during at least two years and without great tension from the proper country).

The main indices among the macroeconomic stability indicators are inflation, GDP and exchange rate shifts. These indicators are interconnected. Thus, the economic stability or its contradiction appears synchronously via all indicators [7].

Let us observe the current situation in Ukraine regarding these indicators. Following 2017 , the inflation indicator in Ukraine was $13.7 \%$ (Fig.1), growing from $12.4 \%$ in 2016. It is proved by the official statistics [8].

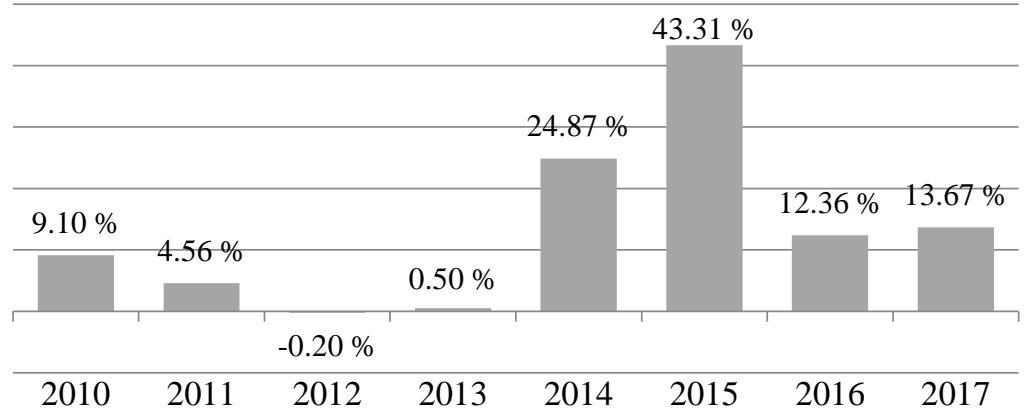

Figure 1. The inflation dynamics in Ukraine during 2010-2017, formed on the basis of [8]

The NBU predicts that inflation in 2018 will be $10.1 \%$, however until the end of 2019 it will decrease to $6.3 \%$. In 2020 the inflation will reach $5 \%$. The negative factors, which affect inflation, include rising of oil prices, a decline in the national currency and elections [9]. Comparing Ukraine's indicators in 2016, when inflation was $43.3 \%$ and was among leaders in 
О. П. Славкова, М. М. Шинкаренко, О. М. Коробець. Аналіз динаміки зміни показників макроекономічної стабільності в Україні

the anti-rating by the inflation level in the world, the economic situation is being stabilized in the country with current and predicted inflation levels. However, our indicators are still far from ideal (not more than $3 \%$ ) and from inflation in the leading countries in the world (Fig. 2).

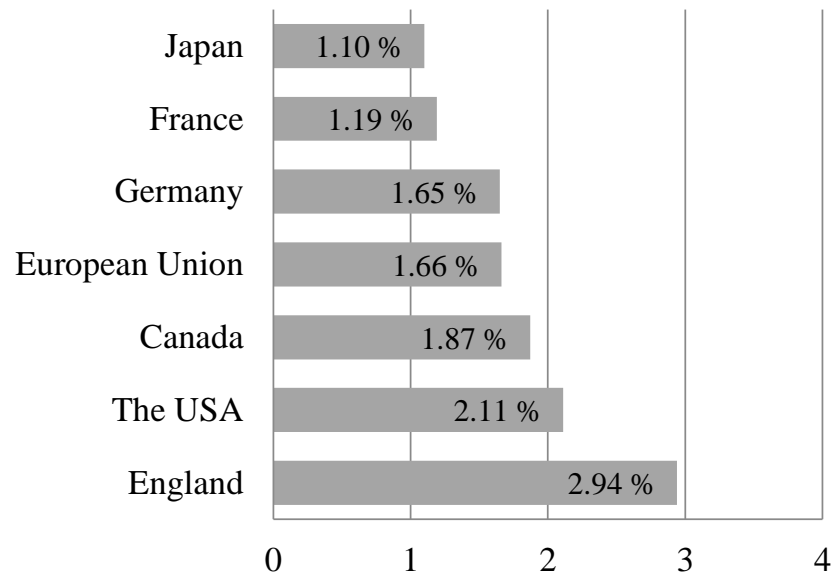

Figure 2. Inflation in the leading countries in 2017, formed on the basis of [8]

Let us then observe the ratio of state deficit to GDP. According to Maastricht criteria, this ratio should not exceed $3 \%$, that we can see during the recent years in Ukraine (Table 1). It proves positive results in the sphere of budget deficit regulation thanks to budget consolidation in 2015 when the problem was aggravated in 2011-2014 when the deficit imbalance was increased to the dangerous level. It required taking measures regarding its prevention, including through formation of the optimal structure of budget expenditures, the creation of the effective system to control the rational and productive use of budget funds [10].

Table 1

Dynamics of the ratio of the state deficit to GDP in Ukraine in 2012-2017, formed on the basis of data from Ministry of Finances

\begin{tabular}{|l|c|c|c|c|c|c|}
\hline \multicolumn{1}{|c|}{ Indicator } & $\mathbf{2 0 1 2}$ & $\mathbf{2 0 1 3}$ & $\mathbf{2 0 1 4}$ & $\mathbf{2 0 1 5}$ & $\mathbf{2 0 1 6}$ & $\mathbf{2 0 1 7}$ \\
\hline $\begin{array}{l}\text { GDP of Ukraine } \\
\text { (mln UAH) }\end{array}$ & 1408889 & 1454931 & 1566728 & 1979458 & 2383182 & 2982920 \\
\hline $\begin{array}{l}\text { Budget deficit } \\
\text { (mln UAH) }\end{array}$ & 50785.7 & 63590.3 & 72030.5 & 30898.2 & 54682.6 & 42093.8 \\
\hline $\begin{array}{l}\text { Rate of the } \\
\text { indicator }(\%)\end{array}$ & 3.604663 & 4.370675 & 4.597512 & 1.560942 & 2.294521 & 1.411161 \\
\hline
\end{tabular}

Currency stability enables importers and exporters to develop long-term growth strategies and reduces investors' needs in currency risk management. The currency stability reduces the threat, caused by the debt emission in a foreign currency for the national business accounting. According to Maastricht criteria, this indicator should not exceed $2.5 \%$. Let us observe the US 
Olena P. Slavkova, Mariia M. Shynkarenko, Olena M. Korobets. Analysis of the Macroeconomic Stability Indicators Changing Dynamics in Ukraine

dollar exchange rate to the UAH. As we can see from table 2, this indicator was higher last year that is why it is early to talk about stability.

Table 2

The exchange rate between UAH and US dollar during 2011-2017, formed on the basis of NBU data

\begin{tabular}{|c|c|c|}
\hline Year & $\begin{array}{c}\text { The average rate of UAH to US } \\
\text { dollar (UAH for 100 US dollars) }\end{array}$ & $\begin{array}{c}\text { Currency fluctuations } \\
(\mathbf{\%})\end{array}$ \\
\hline $\mathbf{2 0 1 1}$ & 800.88 & - \\
\hline $\mathbf{2 0 1 2}$ & 806.74 & 0.731279 \\
\hline $\mathbf{2 0 1 3}$ & 811.90 & 0.639924 \\
\hline $\mathbf{2 0 1 4}$ & 1191.37 & 46.738590 \\
\hline $\mathbf{2 0 1 5}$ & 2185.50 & 83.444390 \\
\hline $\mathbf{2 0 1 6}$ & 2555.45 & 16.927330 \\
\hline $\mathbf{2 0 1 7}$ & 2660.70 & 4.118813 \\
\hline
\end{tabular}

The exchange rate dynamics in Ukraine during 2011-2017 is demonstrated in fig. 3. Taking into account the below data from 2011 to 2013 the exchange rate was stable, but in 2014 it grew rapidly, i.e. UAH devaluation, caused by a number of factors: one refused the traditional mechanisms of the currency stability (fixed rate regime), floatation of the currency; negative external imbalance; weak national production, political instability, absence of the wellconsidered strategy of NBU, which enabled to stabilize the exchange rate.

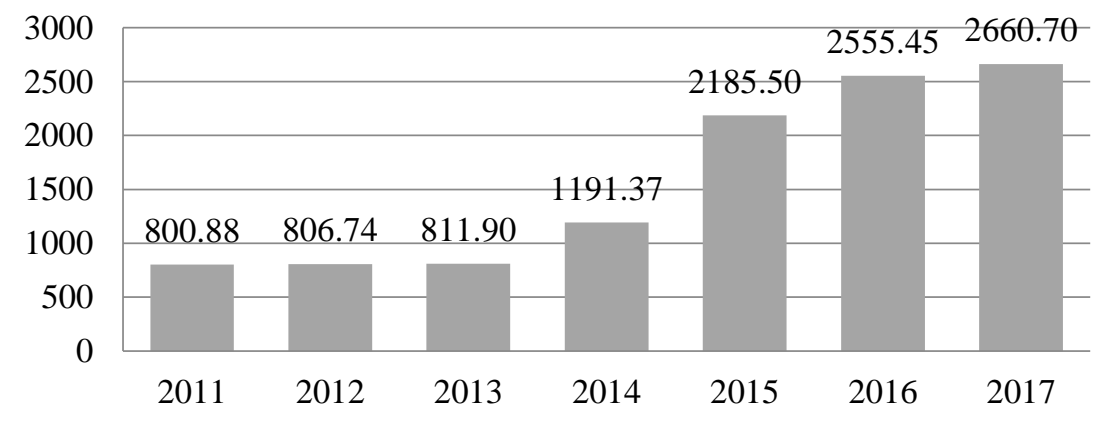

The average rate of UAH to US dollar (UAH for 100 US dollars)

Figure 3. Dynamics of UAH rate to US dollar

Conclusions and perspectives for further scientific investigations. Thus, based on the experience of the developed countries, one can point out a number of urgent principles in the macroeconomic stability analysis:

- $\quad$ the balance of the economic system is key to stability;

- the state of stability cannot be a constant phenomenon, it is periodically changed to the unstable state;

- $\quad$ destabilized factors, which affect the economic stability to any extent. 
As we can see the macroeconomic stability describes, firstly, the efficiency of all factors in the economic development, secondly, the efficiency of the country's economic policy. As for Ukraine's economy, based on the official and most used data, it only begins to stabilize from 2016. Since the renewal is a gradual process, it is poorly reflected on the inhabitants of the country.

\title{
References
}

1. Sorokivska, Z. K. (2011). Sut makroekonomichnoi stabilnosti v perehidnij period [The essence of macroeconomic stability in the first period]. Stalij rozvitok ekonomiki, 7, 26-30. Retrieved from https://uniep.km.ua/pdf/_7_2011.pdf\#page=26.

2. Rajzberg, B. A. (2012). Sovremennyj sotsio-ekonomicheskij slovar [Modern Socio-Economic Dictionary], 264.

3. Evtushenko, N. M., Makarchuk, I. M., Jaremenko, L. M. (2016). Makroekonomichna stabilnist v Ukraini [Macroeconomic stability in Ukraine]. Molodij vchenij, 3, 74-79. Retrieved from http://nbuv.gov.ua/UJRN/molv_2016_3_21.

4. Belyaev, O. O. (2014). Ekonomichna politika [Economical policy], 124.

5. Fedosov, V. (2002). Finansova restrukturizatsija v Ukraini: problemi i naprjami [Financial restructuring in Ukraine: problems and challenges], 64

6. Ljulov, O. V., Pimonenko, T. V. (2017). Teoretichni zasadi kompleksnogo otsinjuvannja makroekonomichnoi stabilnosti [Theoretical foundations of complex evaluation of macroeconomic stability]. Mizhnarodni ekonomichni vidnosini ta stalij rozvitok, 163-164. Retrieved from https://essuir.sumdu.edu.ua/bitstream/123456789/65867/1/Liuliov_macroeconomic_stability.pdf.

7. Lanovij, V. Iljuzija makroekonomichnoï stabilnosti [Illusion of Macroeconomic Stability]. Retrieved from http://tyzhden.ua/Economics/48671.

8. Uroven infljatsii [Inflation rate]. StatBjuro. Retrieved from https://www.statbureau.org/ru.

9. NBU pogirshiv prognoz infljatsii na 2018 rik iz 8,9\% do 10,1\% [NBU worsened inflation forecast for 2018 from $8.9 \%$ to $10.1 \%$ ]. Retrieved from https://gordonua.com/ukr/news/money/-nbupogirshiv-prognoz-infljatsiji-na-2018-rik-z-8-9-do-10-1-453549.html.

10. Analiz ta otsinka bjudzhetnih rizikiv $\mathrm{v}$ konteksti pidvischennja rivnja finansovoi bezpeki derzhavi [Analysis and assessment of budgetary risks in the context of raising the level of financial security of the state]. Retrieved from http://www.niss.gov.ua/content/articles/files/byudz_ryzyky-83060.pdf.

Manuscript received 8 October 2018

\author{
Анализ динамики изменений показателей \\ макроэкономической стабильности Украины \\ ЕЛЕНА ПАВЛОВНА СЛАВКОВА*, \\ МАРИЯ НИКОЛАЕВНА ШИНКАРЕНКО $*$, \\ ЕЛЕНА МИХАЙЛОВНА КОРОБЕЦ ${ }^{* * *}$

\footnotetext{
* доктор экономических наук, профессор, заведующий кафедры бухгалтерского учета Сумского национального аграрного университета, ул. Герасима Кондратьева, 160, Сумы, 40000, Украина, тел.: 00-380-542-222448, e-mail: olena.slavkova.snau@gmail.com

** аспирант кафедры экономики, предпринимательства и бизнес-администрирования Сумского государственного университета,

ул. Р.-Корсакова, 2, г. Сумы, 40007, Украина, тел.:00-380-542-332223,e-mail: marichka115@gmail.com
} 
Olena P. Slavkova, Mariia M. Shynkarenko, Olena M. Korobets. Analysis of the Macroeconomic Stability Indicators Changing Dynamics in Ukraine

*** ведущчий спецчиалист Учебно-научного института финансов, экономики и менеджмента имени Олега Балацкого Сумского государственного университета, ул. Р.-Корсакова, 2, г. Сумы, 40007, Украина, тел.:00-380-542-335475,e-mail: e.korobets@fem.sumdu.edu.ua

В статье проанализированы и разграничены понятия макроэкономической стабильности и стабилизации. Стабилизационная политика влияет на поведение всех экономических субъектов, а значит на эффективность функционирования национальной экономики. Любая страна с рыночной экономикой старается достичь макроэкономической стабильности. Макроэкономическая стабильность характеризует, во-первых, эффективность всех факторов экономического развития, а во-вторых, эффективность политики страны. Стабилизация является комплексным понятием, которое учитывает состояние всех без исключения составляющих экономической системы. Стабилизация рассматривается как стратегический процесс, заключающийся в приближении к экономической стабильности. При условии определения экономической политикой государства критерием стабилизации недостаточного количества конкретных экономических показателей неизбежно нарастание макроэкономических диспропорций. Уделено внимание последствиям макроэкономических процессов, которые влияют на ряд важных показателей страны, таких как повышение международного имиджа страны, повышение рейтинга в мировых показателях, повышение конкурентоспособности отечественной продукции, получение бизнесом стабильного дохода, увеличение бюджетных поступлений, повышение уровня реальной заработной платы и социальных выплат, и тому подобное. Рассмотрена динамика изменений по выделенным показателям, и прогноз дальнейшего развития экономической стабильности страны. Современная макроэкономическая система нашей страны пока что относится к нестабильной экономики, а это обусловливает необходимость разработки эффективной государственной стратегии, направленной на достижение экономической стабилизации и экономического роста. На основе мирового опыта авторами статьи выделены и систематизированы основные показатели и принципы макроэкономической стабильности, которые целесообразно использовать в Украине.

Ключевые слова: макроэкономическая стабильность, стабилизация, экономическое равновесие, индикатор стабильности, инфляция, валовой внутренний продукт, ставка валютного курса.

\section{Mechanism of Economic Regulation, 2018, No 4, 127-134 ISSN $1726-8699$ (print)}

\section{Аналіз динаміки зміни показників макроекономічної стабільності в Україні \\ ОЛЕНА ПАВЛІВНА СЛАВКОВА*, МАРІЯ МИКОЛАЇВНА ШИНКАРЕНКО**, ОЛЕНА МИХАЙЛІВНА КОРОБЕЦЬ ${ }^{* * *}$}

* доктор економічних наук, професор, завідувач кафедри бухгалтерського обліку Сумського начіонального аграрного університету, вул. Герасима Кондратьєва, 160, Суми, 40000, Україна, тел.: 00-380-542-222448, e-mail: olena.slavkova.snau@gmail.com

** аспірант кафедри економіки, підприємництва та бізнес-адміністрування Сумського державного університету, вул. Р.-Корсакова, 2, Суми, 40007, Украӥна, тел.:00-380-542-332223,e-mail: marichka115@gmail.com

*** провідний фахівецьь Навчально-наукового інституту фінансів, економіки та менеджменту імені Олега Балачького Сумського державного університету, вул. Р.-Корсакова, 2, Суми, 40007, Украйна, тел.:00-380-542-335475, e-mail:e.korobets@fem.sumdu.edu.ua 
У статті проаналізовано поняття макроекономічної стабільності та стабілізації. Стабілізаційна політика впливає на поведінку усіх економічних суб'єктів, а відтак на ефективність функціонування національної економіки. Будь-яка країна 3 ринковою економікою намагається досягти макроекономічної стабільності. Макроекономічна стабільність характеризує, по-перше, ефективність всіх факторів економічного розвитку, а по-друге, ефективність економічної політики країни. Стабілізація є комплексним поняттям, що враховує стан усіх без винятку складових економічної системи. Стабілізація розглядається як стратегічний процес, що полягає у наближенні до економічної стабільності. За умови визначення економічною політикою держави критерієм стабілізації недостатньої кількості конкретних економічних показників неминучим $є$ наростання макроекономічних диспропорцій. Приділено увагу наслідкам макроекономічних процесів, які впливають на ряд важливих показників країни, таких як підвищення міжнародного іміджу країни, підвищення рейтингу в світових показниках, підвищення конкурентоспроможності вітчизняної продукції, отримання бізнесом стабільного доходу, збільшення бюджетних надходжень, підвищення рівня реальної заробітної плати та соціальних виплат, тощо. Розглянута динаміка змін за виділеними показниками, та прогноз подальшого розвитку економічної стабільності країни. Сучасний макроекономічна система нашої країни наразі відноситься до нестабільної економіки, а це обумовлює нагальну потребу розробки ефективної державної стратегії, спрямованої на досягнення економічної стабілізації і економічного зростання. На основі світового досвіду авторами статті виділено та систематизовано основні показники та принципи макроекономічної стабільності, що доцільно використовувати в Україні.

Ключові слова: макроекономічна стабільність, стабілізація, економічна рівновага, індикатор стабільності, інфляція, валовий внутрішній продукт, ставка валютного курсу.

JEL Codes: E60, O11, O47

Tables: 2; Figures: 3; References: 10

Language of the article: English

Лimepamypa

1. Сороківська, 3. К. Суть макроекономічної стабільності в перехідний період [Електронний ресурс] / 3. К. Сороківська // Сталий розвиток економіки. - 2011. - № 7. - С. 26-30. - Режим доступу : https://uniep.km.ua/pdf/_7_2011.pdf\#page=26.

2. Райзберг, Б. А. Современный социоэкономический словарь / Б. А. Райзберг. - 2012. - М. : ИНФРА-М. - $264 \mathrm{c}$.

3. Євтушенко, Н. М. Макроекономічна стабільність в Україні [Електронний ресурс] / Н. М. Євтушенко, І. М. Макарчук, Л. М. Яременко // Молодий вчений. - 2016. - № 3. - С. 74 79. - Режим доступу : http://nbuv.gov.ua/UJRN/molv_2016_3_21.

4. Бєляєв, О. О. Економічна політика / О. О. Бєляєв. - К. : КНЕУ. - 2014. - 124 с.

5. Федосов, В. (2002). Фінансова реструктуризація в Україні: проблеми і напрями. - 2002. - К. : КНЕУ. $-64 \mathrm{c}$.

6. Люльов, О. В. Теоретичні засади комплексного оцінювання макроекономічної стабільності [Електронний ресурс] / О. В. Люльов, Т. В. Пімоненко // Міжнародні економічні відносини та сталий розвиток. - 2017. - С. 163-164 - Режим доступу: https://essuir.sumdu.edu.ua/bitstream/123456789/65867/1/Liuliov_macroeconomic_stability.pdf.

7. Лановий, В. Ілюзія макроекономічної стабільності [Електронний ресурс] / В. Лановий. - Режим доступу : http://tyzhden.ua/Economics/48671.

8. Уровень инфляции // СтатБюро. [Электронный ресурс]. - Режим доступа : https://www.statbureau.org/ru.

9. НБУ погіршив прогноз інфляції на 2018 рік із 8,9 \% до 10,1 \% [Електронний ресурс]. - Режим доступу : https://gordonua.com/ukr/news/money/-nbu-pogirshiv-prognoz-infljatsiji-na-2018-rik-z-89-do-10-1-453549.html.

10. Аналіз та оцінка бюджетних ризиків в контексті підвищення рівня фінансової безпеки держави [Електронний ресурс]. http://www.niss.gov.ua/content/articles/files/byudz_ryzyky-83060.pdf. 